\title{
Market and Labour Control in Digital Capitalism ${ }^{1}$
}

\author{
Philipp Staab* and Oliver Nachtwey \\ "Institute for the History and Future of Work, Berlin, Germany, staab@igza.org, \\ https://www.researchgate.net/profile/Philipp_Staab
}

"Technical University of Darmstadt, Darmstadt, Germany, nachtwey@ifs.tudarmstadt.de, https://www.ifs.tu-darmstadt.de/index.php?id=3572

\begin{abstract}
Theorists of post capitalism have recently argued for a more or less inevitable end to capitalism. They assume that private accumulation is systematically blocked by the inability of capitalist corporations to create revenues by setting prices as they lose control over the reproduction of their commodities and that in this process, capitalist labour will eventually disappear. Drawing on a case study of Amazon and thoughts on the policies of other leading digital corporations, we challenge these assumptions. Key corporate players of digitization are trying to become powerful monopolies and have partly succeeded in doing so, using the network effects and scaling opportunities of digital goods and building socio-technical ecosystems. These strategies have led to the development of in part isomorphic structures, hence creating a situation of oligopolistic market competition. We draw on basic assumptions of monopoly capital theory to argue that in this situation labour process rationalization becomes key to the corporation's competitive strategies. We see the expansion of digital control and the organizational structures applied by key corporate players of the digital economy as evidence for the expansion of capitalist labour, not its reduction.
\end{abstract}

Keywords: Digitalization, capitalism, digital labour, digital economy, Amazon, Google, market, control, organization

\section{Introduction}

Analysis of the current state and predictions about the future development of capitalism frequently tend to exaggerate the role of individual elements of economic systems. They often start by considering the sectors that determine structure, because, in economic terms, they account for the largest portion of employment and contribute most to creating added value. But these two factors tell us little about the material nature of work, about labour processes, about the use of the labour force, about opening new markets, or about control at the workplace. In short, they contribute little to answering questions raised by sociological theories of capitalism. Such theories analyse capitalism on the basis of conditions of production, the use of labour, specific forms of market inclusion, and organization politics, rather than focusing only on the structures of employment and creating added value.

Considering the analysis of contemporary capitalism, digitization has emerged as a meta-trend, which diverges from the familiar borders that separate economic sectors or branches (Brynjolfsson and McAfee 2016). Currently, there are increasing indications that we are in the midst of new wave of technological innovation fuelled especially by three factors: (1) revolutions in data storage, processing, and retrieval (big data); (2) the growing dissemination and interconnectedness of digital devices

\footnotetext{
${ }^{1}$ We thank two anonymous reviewers for intelligent remarks and suggestions.
} 
among producers and consumers; and (3) the development of intelligent algorithms. Digitization has the potential to affect all areas of production and all segments of the labour market and can thus serve as a basis for reasonable analysis of transformations in contemporary capitalism. Digitization is transforming work in numerous different ways, and changing business strategies, job profiles, organizational policies, chains of productions, and forms of employment as well as labour relations.

However, in recent literature on the digitization of the economy, voices have emerged describing digitization as the gravedigger of capitalism. Rifkin (2015) and Mason (2016), to name just two of the most prominent authors, both argue for the inevitable end of capitalism in the light of digitization. Both authors argue that with the rise of the Internet of things, the logic of zero marginal costs, which characterizes digital goods (the reproduction of a product comes at almost no costs), will become ubiquitous in the economy. As things in the future economy come almost for free, Rifkin and Mason argue, it becomes very hard for companies to reap profits. At the same time the rise of the sharing economy and collaborative peer production are supposed to be a source of a new non-capitalist production model (Mason 2016, $141 \mathrm{ff})$. In this new "post capitalist" economy, in Mason's $(2016,181)$ terms, "Info-tech makes the abolition of work possible", meaning that labour is freed from the chains of rationalization and control.

At the core of these theories is the assumption that private accumulation is systematically blocked by the inability of capitalist corporations to create revenues by setting prices as they lose control over the reproduction of their commodities in an economy where people have the power to make most things in non-capitalist production models themselves. In this article we want to address the question if, from an empirical point of view, this is actually a proper description of current developments in "digital capitalism" (Schiller 1999). We ask two questions in particular: Is the digital economy really moving towards a state in which corporations lose all control over markets, which then become increasingly decommodified? And second, is there really any end to capitalist labour or at least a reduction in capitalist modes of exploitation connected to the trend towards digitization?

When asking these questions, one has to acknowledge that there is a strong line of research in digital labour offering arguments against the thesis of an inevitable end of capitalism and the liberation of labour. Examples of authors engaged in this strand of research abound. To name but a few: Scholz (2012) describes numerous transformations of digital labour while Dyer-Witheford (2015) introduced the term cyber-proletariat to capture the logic of exploitation of digital labour. Following transnational chains of production from mineral extraction, assembling work of digital hardware to software production and services, Fuchs (2014) shows how digitization enhances profit extraction by enabling a more frictionless global division of labour. Fisher and Fuchs (2015) show the continuous strength of Marxian socioeconomic theory when applied to digital capitalism.

However, in our view, to counter theories arguing for our path into post capitalism such as Rifkin and Mason in particular, one would have to show that in spite of the particular characteristics of digital commodities, companies dealing in such products on one hand manage to nevertheless gain market control and do so, on the other hand, on the basis of the exploitation of human labour. The aim of this article is thus to exemplify the connection of market and labour control empirically. Drawing on a case study of the company Amazon, we will show how key corporate players in the digitization process manage to form quasi-monopolies in order to gain market control. We argue that there is a high probability for digital giants of the present-in particular 
Amazon, Google, Microsoft, Apple, and Facebook-to develop increasingly convergent product portfolios, thereby creating a situation of a market dominated by large oligopolies. Focussing on Amazon, we then show how such oligopolies in digital capitalism create profit mainly by enforcing rationalization and labour control. Our analysis will lead us to the development of certain theoretical terms, which, in our view, could prove helpful in the analysis of digital capitalism when applying them to other cases. We will tentatively explore these terms in the context of theoretical assumptions of Fordist and post-fordist capitalism.

In order to show the systematic connection between market- and labour control in digital capitalism, we use a basic assumption drawn from classical industrial sociology theories of labour and monopoly capital (Sweezy and Baran 1966; Braverman 1998). While one can draw many questions from monopoly capital theory when applying it to digital capitalism, in order to make our argument, we will focus exclusively on the relationship of monopolies, price setting and labour control. Classical monopoly capital theory argued that monopolistic or oligopolistic companies managed to create surplus by maintaining the capability of high-level price setting and cutting costs at the same time. In industrial sociology's labour process debate, Braverman and others (Braverman 1998; Edwards 1979; Burawoy 1982) showed how the cost cutting aspect of the production model was enforced especially by enhancement of labour control, thus demonstrating the systematic relation between market- and labour control in the process of capitalist production. We argue that we can understand current developments in digital capitalism when using such a perspective as, in light of oligopolistic tendencies, competition about labour efficiency becomes more and more essential to capitalist reproduction. In our view, this is evidence against theories of post capitalism claiming that capitalist labour is coming to an end.

In the first section of this article, we will argue for a perspective, which focuses in particular on leading digital economy companies in order to assess broader changes in the economy. We will then confront contemporary theories of post capitalism with the strategies of leading digital economy companies to build socio-technical ecosystems in order to stabilize their current quasi-monopolies. In the second section we will start exploring more deeply the mechanisms applied by Amazon in order to retain its monopolistic position in E-Commerce and elaborate our assumption that the digital monopolies of the present increasingly converge on their supply side, thus creating a new situation of market competition. Drawing on a key theorem of traditional monopoly capital theory, in the third section, we will then show how in this situation, rationalization and the enforcement of labour control become more and more essential to the creation of profits. Again, we will elaborate tentative theoretical concepts, considering a new mode of labour control and a new kind of workforce that could be useful in further comparative research. In the fourth and concluding section we summarize our arguments made against theories of post-capitalism and argue that digital capitalism is maturing in the usage of digital technologies, since it is following tracks well known from the history of industrial societies, especially labour control.

\section{Key Corporate Players as Digital Monopolies}

In order to understand the relationship between market and labour control in contemporary digital capitalism, it is important to look at key corporate players in the digitization process as such companies set the pace for the rest of the economy. Besides introducing new digital strategies into existing modes of production and distribution, key players of the digital economy, such as Amazon, Google, Microsoft, Apple or Facebook pursue a strategy of disruption. They literally bypass familiar forms of open- 
ing up markets, which usually concentrate on optimizing minor improvements of existing products; instead, their aim is to radically challenge the functional logic of established markets. Disruptive technologies and business strategies draw more traditional branches of the economy into what has been called the "digital vortex" (DyerWitheford 2015). Systematically generated ruptures affect the institutional order of labour markets, companies, and organizations as well as labour processes and the significance of labour as a commodity. In short, they lead to pressures for change in diverse areas of the world of work, triggering deinstitutionalization and transformation processes. This pressure of change results, in turn, in the emergence of new social orders, which, taken together, are promoting a new type of capitalist economy.

The best-known and most influential of the key digital economy companies have their main offices in Silicon Valley or elsewhere on the American west coast. They provide the infrastructure for the World Wide Web, determine digital forms of communication and user activities, and supply the software and hardware needed for digital networking. As the central (or, in the language of research on operational networks, "focal") operator of strategic digital networks and the direct or indirect employer of hundreds of thousands of people, these key players shape working conditions not only for the commercial Internet but also for many other sectors. In light of this, scholars such as Fuchs (2014) have called for a perspective that also takes the global peripheries of Internet and technology companies into account. According to this view, Foxconn workers who assemble Apple I-Phones are a systematic element of digital capitalism, as are those working in coltan mines in various regions of the world.

The economic transactions of leading digital economy companies-Google, Apple, Amazon, Facebook, and Microsoft in particular-use two different currencies: money and information. Google or Facebook accounts are free at first, but users "pay" with personal information that is in effect the companies' primary capital. These data giants improve their market position by accumulating user data that allows them to constantly optimize the algorithms structuring their companies' service and production processes. On the one hand, these permanent feedback loops between users and the digital production process heighten the value of user experiences, as customers' wishes and preferences can be employed to constantly improve services. On the other hand, technical processes that rely on user data are also the basis for targeted advertising and big-data applications that are in fact the core business of companies like Google or Facebook.

Authors like Mason and Rifkin argue that since these companies deal to a significant amount in digital commodities, it is hard for them to run long term profitable businesses. Digital commodities entail a logic of zero marginal costs (Rifkin 2015), which means that in a situation of market competition, prices have to fall close to the point where they match with production cost, which apparently are close to zero, finally making it impossible to generate profits. As digital hardware becomes gradually cheaper and robotization more broadly available, the logic of zero-marginal costs spreads from the digital economy to basically every industry. Furthermore, as means of production are being decentralized in the rise of 3D printing, the Internet of things or the maker movement, supported by the rise of peer production and sharing practices, the production of commodities increasingly happens outside of traditional corporations, finally rendering them redundant. While Rifkin sees a historical inevitability in the rise of "collaborative commons" as a dominant form of commodities, Mason $(2016,118 f)$ argues that companies could try to retain control over price setting by building monopolies. However, like Rifkin, Mason argues that these attempts will be 
failing in the end as they cannot stop the rise of open source and peer production. In opposition to these assumptions, we argue that leading digital economy companies have been working quite successfully on building monopolies in certain areas in order to control markets and obtain the power of price setting. They do so by creating social closure through socio-technical ecosystems in order to create strong customer retention.

\subsection{Building Closure in Socio-Technical Ecosystems}

In the visions of theorists of post capitalism, digitization continues to be frequently associated with hopes that it will decentralize economic life and contribute to democratizing it in the process. According to these expectations, in the digital capitalism of the future, production knowledge will be spread widely, with computer nerds and techie communities collaborating to devise innovations that are made freely available to all. Smart apps and customer-friendly services will contribute to shaping a world that offers consumers and producers more choice and more opportunities to get involved. But a closer look at the centrepiece of digital capitalism, the Internet economy, reveals the sobering logic of the digital market. Today, digital capitalism's markets are a far cry from the models of the neoclassic economy based on complete competition between numerous suppliers of similar goods and services, none of which dominate the market, and transparency with respect to all relevant information. Instead, the key markets of digital capitalism reveal phenomena familiar to what has been called "monopoly capitalism" in 1960s and 70s debates within industrial sociology (Baran and Sweezy 1966, Braverman 1998): concentration and control of markets and monopolization.

In the digital economy of today, monopoly tendencies result from systematic Matthew effects that have two main causes. Firstly, on the supply side, there are specific effects of scale; that is, the development costs of digital products are high, but the marginal costs of producing each unit (of software, for example) are then extremely low. Subjecting theories of post capitalism to empirical scrutiny, we find that this dynamic of (close to) zero marginal costs does not prevent the rise of powerful monopolies. On the contrary, as a result of zero marginal costs, companies can sell large quantities of products at relatively low prices or even distribute them free of charge, for example as a means of promoting long-term customer loyalty. Moreover, the larger a company is, the higher are its advantages in terms of costs and speed when developing new products and the more diverse is its product portfolio. In other words, large companies profit from systematic superiority over their smaller competitors. Secondly, on the demand side, specific network effects (Romer 1990; Shapiro and Varian 1999, 173-226; Rochet and Tirole 2003) come into play which result from the fact that the benefits of many digital products increase as more people use them. Once a critical mass of users is "on board", then it becomes attractive for more and more people to also enter the system. When the demand for a successfully established product reaches a specific magnitude, demand becomes a self-reinforcing process. Network gains thus make strong competitors stronger and weak ones weaker. If network effects and effects of scale occur together, they promote processes of monopolization or oligopolization and the development of "winner-takes-it-all markets" (Frank and Cook 1995), in which smaller companies fall behind.

Classic monopolization processes in industrial monopoly capitalism were often based on "natural monopolies" (Varian 1997, 397-399) -they are in fact in some ways similar to the monopolies of digital capitalism. With respect to their material prerequisites, natural monopolies are based on extremely high fix costs and variable 
costs that are relatively low in comparison. Telecommunications, energy, and water utilities as well as rail services were dependent on comprehensive, cost-intense infrastructure networks, while the commodity or service itself was relatively inexpensive. Competitors found it difficult to deal with the resulting effects of scale, once the necessary infrastructure was in place. Building new rail or telephone networks was seldom worthwhile for new providers. But this has changed in digital capitalism. Currently, Google more or less holds a monopoly as a search-engine provider. But the fact that this position was held until rather recently by Yahoo demonstrates that the monopolies of digital companies are-or at least were in the past-highly "volatile monopolies" (Dolata 2015). Until not so long ago, creative thinkers could capitalize on the low marginal costs of digital products without being dependent on one of the Internet giants. A good idea and some venture capital were enough to revolutionize a market and knock the frontrunner off its throne. Theorists of post capitalism like Rifkin and Mason have this situation in mind when arguing against the likelihood of monopolization in future digital capitalism.

But a close look at the digital giants of today reveals the fact that digital companies have learned from this kind of experience in the early days of the Internet. As digital capitalism approaches adulthood, large corporations are aiming to create sociotechnical ecosystems integrating hardware and software that meet as many user needs as possible and make it harder for users to switch to another provider. Establishing such socio-technical ecosystems occurs in a number of steps. First, companies acquire their competitors in order to expand their own share of markets. They also enlarge their product portfolio, incorporating new know-how by buying companies that do not appear at first glance to belong to their core operations. Amazon, for example, acquired online retailers that sold a wide range of goods and successively made the transition from a digital bookseller to an all-round retailer, at the same time it invested in robotics, web-services, and hardware companies. Google is also one of the most active companies when it comes to mergers and acquisitions and invests in numerous companies whose connection to its core business of Internet searches and advertising only becomes apparent on closer inspection. It has for example bought Nest, a start-up that developed smart thermostats and smoke detectors, and become the world's largest producer of robotic technology thanks to various acquisitions. This expansion of Google's product range is, of course, by no means based on random decisions. The Nest deal aims to establish Google's position in the emerging market for "connected homes" systems (a market also targeted by Apple and Amazon). And as outlined above, Amazon's investments in robotics promote optimization of their storage and transportation logistics systems.

A company's own hardware devices play a key role in embedding users in closed socio-technical ecosystems. They offer customers a number of synchronized and interlinked programs and services. The anchor product-whether it's an iPad, a Nexus, a Surface or a Kindle-serves as a digital hub for all forms of communication and coordination. Once a user is integrated into such a socio-technical space for communication-because, for example, she or he stores data and files it in a specific provider's cloud-then other applications from the same provider dock into the existing structure. This results in closed systems that are as complex as they are highly personalized and systematically impede changing to another provider, since users would then generally face a loss of aggregated data, with unpleasant consequences. Thus, building socio-technical ecosystems, together with the network effects and scaling possibilities of digital goods, serves the stabilization of digital monopolies. In order to explore this dynamic in detail and link it to the logic of price setting and creation of 
profits, we will now take a closer look at the company Amazon as a prime example for building a monopoly in the digital economy.

\section{Monopolies Amazon-Style}

By far the largest online retailer, Amazons' worldwide sales recently surpassed those of its next competitors taken together (Dolata 2015). Well known for sacrificing profits in favour of business expansion for most of the company's history, Amazon has recently shown big profits thanks to the expansion of its lucrative cloud computing business. For the second quarter of 2016 , the company reported $\$ 2.89$ billion in revenue from its Amazon Web Services business and $\$ 17.67$ billion from its retail business. However, operating income from Amazon Web Services in the same time period amounted to $\$ 718$ million, up from $\$ 305$ million for the same period in 2015 , which was slightly more than the operating income generated by its North American retail business (Wingfield 2016). In the following section, we will discuss various decisive parameters of the rise of Amazon as monopoly, in order to exemplify mechanisms of how monopolies are being built in the digital economy. Following a thick description of Amazon's business strategy (2.1), we provide a tentative theoretical generalization based on our analysis of Amazon, which can be helpful when studying other cases (2.2). We then return to Amazon (3) focusing primarily on the aspects of rationalization and labour control in the company (3.1) and then again develop tentative generalizations in order to frame concepts which could be applied to other cases.

\subsection{A Brief History of the Amazon Ecosystem}

What is Amazon: a retailer or a technology company? For a long time, Amazon CEO Jeff Bezos was laughed at by other pioneers of the Internet age for uncompromisingly asserting that the second answer to this question was correct (Stone 2013). Amazon's founder was adamant about his plan to build a digital services company, rather than just another retailer. Even in 1994, the year it was established, Amazon was far ahead of its time albeit forced to offer "analogous", tangible goods-in the mid-1990s, the technical prerequisites for digitization of most of the products offered simply were not in place. Amazon's original focus, Internet book sales, offers especially convincing evidence of this observation. The first digital reader entered the market in 1999 (the Rocket eBook marketed by NuvoMedia), five years after Amazon came into existence (the Kindle went on sale for the first time in 2007). Since then, the company has demonstrated its characteristic drive to expand in this market segment. In 2014, Amazon's Kindle accounted for over two thirds of US e-book sales. But e-readers and other mobile electronic devices make up only a fraction of the company's huge technology network, which has developed internally with respect to its organizational structure, personnel management, and human relations strategies, as well as externally on a variety of markets, in pursuing the company's strategy of integrating these markets comprehensively into its activities.

Amazon's policy targets the transformation of established markets and the generation of new ones by means of digitization. The book trade, Amazon's "home base," is a paradigmatic example of how it has pursued this policy. On the first level of transforming the book market, Amazon entered the established market for printed books as a new competitor; in effect, it first simply reorganized the classic booksellers' model by selling books on a new, digital market. This large-scale virtual market was successful especially because it offered the advantage of "one-stop shopping" for a huge selection of titles from one bookseller. Amazon successively expanded the range of available goods, to the point that today there is hardly a product in existence 
that can't be bought from Amazon. The bookseller has become a gigantic-and potentially unlimited-digital department store. On the second level of this process, Amazon's platform capitalism was introduced to realize a much more active transformation of its markets, in which its Internet platform was used not only as a digital market place but also as a digital production system. Meanwhile, this system has been especially successful on the book market, swallowing up the business that was previously the domain of publishing companies - in effect, Amazon's suppliers. It is part of Amazon's policy to use its dominant position on the market to demand aboveaverage discounts or other concessions from publishers and to pull no punches in this kind of price battle. In fact, as Amazon has become a sales platform without which no publisher is able to survive, the company has become very successful in setting the prices on the side of its suppliers.

But using the Amazon platform as a production system is part of a much more farreaching strategic goal. Ultimately, the aim is to render publishing houses, as intermediaries between authors on the one side and sales and distribution (Amazon) on the other, completely superfluous and in effect throw them out of the game. Intelligent editing software and, of course, the Kindle as Amazon's own consumer device are the digital means for ensuring the success of this planned revolution in publishing. Amazon in this case is pursuing a strategy for the book market that resembles what Apple has developed on the music market with the iPod and the iTunes Store. Steve Jobs beat out Jeff Bezos with respect to the lucrative digital music market. But Bezos adapted the Apple business model for his attack on the book market in linking the Kindl and the Amazon platform (Stone 2013). Amazon offers a self-publishing function with which authors can market their own e-books and pocket a larger share of revenue from sales than what they would earn by publishing their e-book with a normal publishing company. But these authors are also not integrated into the paternalistic system of a publishing house. Amazon dictates price policies for self-published e-books, purportedly in the interests of customers. New, more flexible, performancelinked payments for authors in the self-publishing scheme were recently introduced. Payments are now based on the number of pages read, rather than the number of ebook downloads.

\subsection{Markets: Digital Invention, Analogous Destruction, Convergence}

In shaping markets, Amazon follows a logic of digital creation, in which "analogous" market structures are disrupted. In our view, this seems to be a characteristic which applies to other digital monopolies as well and finally leads to oligopolistic rather than monopolistic market structures: The installation of socio-technical ecosystems has an important side effect. Although the core business of each Internet Corporation lies in a different sector (advertising, software, consumer entertainment electronics, retail sales), their supply structure is increasingly convergent. They constantly observe and adapt to one another, leading to in part "isomorphic" (DiMaggio and Powell 2000) structures on the supply side. Although companies like Google and Amazon are not competitors in their classic core fields of business, they now increasingly compete with one another.

Such developments, on first sight, could support theories of post capitalism: Even though companies like Amazon, Google, Apple, Microsoft or Facebook are trying to build solid monopolies, the competition which arises from convergence of their supply structure could again put pressure on prices making it impossible for these companies to set prices for their products beyond their near-zero production costs. 
There are, however, at least two strategies these companies use to counter such a situation. First, due to the growing similarities in the goods and services offered, competition for profits is played out mostly on the field of innovation. All key corporate players follow ambitious innovation strategies, be it by acquisitions of promising startups or by spending huge amounts of capital on research and innovationGoogles' "moonshot factory" is only the most prominent example for these attempts. The radical orientation towards innovation has impregnated the digital economy with an ideological narrative based on what seems to be a trivialization of Schumpeters' economic theory: Schumpeter countered the idea shared by neoclassical and Marxist economic theorists alike, that prices are the weapon of choice in the war for markets, by asserting that the decisive variable in modern markets was the competition fuelled by "new goods, new technology" (Schumpeter 1983). In Silicon Valley ideology, confirmation for this dictum can be found in the core companies of digital capitalism, whose strategies for the future rely especially on disruptive innovations-sweeping technological advances with benefits that are capable of restructuring or even generating consumer needs and entire markets in the process (Christensen 1997). The analytical suggestion made by this narrative is that, after the manager and shareholder models of recent decades, the entrepreneur is returning in digital capitalism as a key figure of company leadership (see, for example, Thiel and Masters 2014). Because of the increasing focus on innovations that may be unprofitable in the short run but revolutionary in the long term, the ideal type of the audacious, far-sighted entrepreneur described by Schumpeter is supposed to be in demand again and in fact entrepreneurs like Steve Jobs, Marc Zuckerberg or Jeff Bezos are being glorified today just like Bill Gates was in the 1990s. There is little evidence, however, that, with the renaissance of the entrepreneur, the model of patrimonial management is also returning, in which the people at the helm, like Fordist captains of industry, enter into long-term relationships of social obligations with their employees. Instead, companies like Amazon engage both in the tightening of repressive labour control and the externalization of formal employment into officially self-employed forms of work.

This leads us to the second strategy large digital economy companies apply in order to extract profit in situations of oligopolistic competition, namely the enforcement of rationalization and labour control. Whether we consider large corporations, independent platforms, or platform companies like Amazon, the digitization of marketplaces is not only currently revolutionizing the trade with analogous and digital products - it is transforming trade with labour as a commodity. As can be learned from classical monopoly capital theory, large corporations can maintain setting prices at high levels while still competing by cutting costs of production through automation and intensification of labour control. Again Amazon proves to be a significant example for strategies applied in order to maximize profit by restructuring labour processes.

\section{Labour in Digital Monopolies}

Amazon's radical market policy is complemented internally by systematically exploiting its technological potential for enhancing the effectivity of the goods and services it offers. The main targets of new digital applications involve the expansion of digital forms of control over employees and increased use of potentials for automation that result from current developments in robotics. 


\subsection{Technology and Labour Control at Amazon}

Amazon is a leader in developing and implementing automation technologies. When Jeff Bezos staged a test flight of a delivery drone in late 2013 for the media and announced that a drone-based delivery system would be in place within five years, many observers held this for a publicity stunt that aimed mostly to signal to other delivery providers that Amazon could do without their services, so they would do well to keep their prices low. But when the company filed a patent for its own delivery drone, designed for use in the Amazon Prime Air program in April 2015, it became apparent that such announcements of an increasing automation of distribution were not just empty threats (Rose 2013; Zimmermann 2015). And there are signs elsewhere that plans exist to implement systematic automation into distribution. Amazon is merely one example of a trend that includes technologies such as self-driving cars and trucks slated to revolutionize the freight transport and distribution business.

While it is yet undecided to what extent automation can be realized in these areas, warehouse and storage logistics offer examples to illustrate radical automation processes. Industrial warehouses for products with little variation and fluctuation have already been highly automated for some time. But to date, existing automated systems have been unable to deal with the demands of booming Internet retailers, with their huge variety of products and high levels of fluctuation. Now, a shift in this area of low-level service work, which is particularly labour-intensive, seems to be in the offing. And again, Amazon is one of the pioneers. In 2012, Bezos acquired the robotics company Kiva Systems (renamed Amazon Robotics in 2015), which specializes in automated material-handling systems for online retail business. Traditionally, there are two large labour-intensive areas in mail-order warehouses: order "pickers" collect the goods from various shelves, which "packers" then prepare and label for shipping. Kiva developed a technical system capable of substituting human pickers almost completely, based on a simple and ingenious idea. To render the pickers superfluous, the goods are stored on portable storage units, a kind of robot vehicle, rather than fixed shelfs. When a particular product is needed, software guides the robot vehicle to the appropriate storage unit, where it is retrieved and brought to the packing station. These automated robots navigate the huge warehouse with the help of bar codes on the floor and sensors that also prevent collisions. The vehicles also manage their own energy resources, heading for a power station as needed. Since Amazon acquired Kiva Systems, little news has leaked out. Staff in the company's sales department has been reduced considerably. Observers in this sector believe that Amazon has no interest in sharing the company's technological and strategic expertise with possible competitors and is developing a fully-automated system tailor-made to meet its own distribution needs. These speculations are fuelled by information that Amazon recently began taking steps to introduce new automation technology in its "fulfilment centres" (the company's term for its warehouses) in the USA. In fall 2013, Jeff Bezos announced that pickers had been almost completed substituted by machines in three of Amazon's main centres in the USA, and the company has reported that this step will double or treble the centres' productivity (Fuchs 2013).

However, neither delivery drones nor fully automated warehouses have been implemented on a broader basis so far. While we can only speculate on the reasons for this instance-is the technology not ready yet? Is it not cost efficient facing cheap human labour?-one can be sure that leaking information about possibilities of automation always aims to put pressure on wages as human workers then supposedly compete with machines even when these technologies are not applied yet. 
However, in its warehouses, Amazon has shown huge efforts in building a tight and efficient system of digital control focusing not so much on automation but on the extraction of value from human labour. A barcode system similar to the one that steers rolling shelves through Amazon's warehouses aids its thousands of human employees in finding their way around the company's warehouses. But the employees' barcode scanners can do much more. They serve as a kind of time card for clocking working hours but also register incoming goods. And the scanners show pickers the shortest route through the warehouse, thus further contributing to greater employee efficiency. Union officials also report that the device is equipped with a microphone and camera for monitoring employees. In Germany, Amazon has confirmed the existence of this equipment but says it is not used, where it would violate existing data privacy laws - a statement strongly contested by union officials.

The scanner system means that Amazon can monitor not only the exact location of all goods stored but also track its employees' activities-where they are, how many articles they handle in a given period of time, and how their performance compares to that of their co-workers. In performance review meetings with employees, management can draw on the symbolic power of "objective" numbers provided by the digital control system in Amazon's warehouses, which allows precise assessment of individual employees' work. In the process of industrialization of service work, no fundamental distinction is made between managing products and managing human labour. Barcodes are merely the visible emblem of a digital control system that literally connects products and labour. Amazon's fulfilment centres represent a kind of laboratory set-up for developments that are underway in diverse branches of the economy. Amazon's digital control system is based on comprehensive monitoring of all data on the company's employees deemed relevant for its operations. Today, intelligent software on company computers as well as GPS data on the whereabouts of especially mobile employees or e-mail and voice communication from company cell phones supply a wealth of data that can be evaluated according to criteria that serve supervision and control strategies in a wide range of jobs and sectors-a process framed as "screening" in management literature.

At Amazon, the opportunities of digital technology are also used to loosen and potentially dissolve the long-term, predictable integration of workers within the company. The less autonomous action is required of pickers and packers in the work process, the easier they are to replace. Amazon takes advantage of the short period needed to train new employees (union officials speak of a training period of three to five hours for pickers and packers) to ensure that it can react flexibly to systematic fluctuation in demand. During busy periods such as before Christmas, Amazon in some cases employs more temporary employees than regular staff (Hegemann 2014). These employees are not only object to digital control at work. In 2013 German public service broadcasting ran a controversial documentary about the working and living conditions of Amazons temporary employees, many of them temporary migrants from other European countries. The documentary reported a tight system of exploitation of and control over these workers who were housed close to the warehouses in social isolation and whose every moves were, in the case of the Amazon complex in Bad Hersfeld, monitored by security guards connected to ultra-right wing neo-nazi groups who systematically violated workers' privacy rights (Kwasniewski 2013). While inside the warehouses, the company aims to control its labour force as directly as possible by digitizing organizational processes, in case of temporary employment, it seems to expand its control efforts to the private lives of workers. 
The trend towards a digital transformation of immediate market access to labour is manifested in an even more radical form in Amazon tools such as Mechanical Turk and Amazon Home Services, two of the Amazon Web Services flagships. Mechanical Turk is a pioneer crowdsourcing platform that businesses or individuals, called Requesters, can use to seek workers for paid tasks. For example, if a company wants a large number of photographs from its annual party to be labelled with amusing titles for its company intranet, a so-called Provider or Turker can apply to do the task for a fixed price, usually a few cents per image. This crowdsourcing (Howe 2006) model uses digital methods to shift discrete tasks from a company context to a mass of external, self-employed workers. In the crowdsourcing sector, Amazon is just one of many players. In 2014, about half a million people from 190 countries, in their majority from the USA and India, were using Mechanical Turk (Chandler and Paolacci 2014, 184). Companies like Siemens, IBM, SAP, Bosch, or BMW run their own crowdsourcing platforms that list not only simple digital tasks for so-called "clickworkers" but also jobs for qualified workers, for example in design or software development (Boes et al. 2015). In the US, Amazon has also launched a digital platform for placement of non-digital workers, Amazon Home Services. Here, clients can purchase the services of cleaners, handymen, landscapers, contractors, and others. And here again, Amazon is just one big fish in a pond with numerous other service providers, including a number of startups and large corporate players-Google for example recruited a tech team from failed home service startup Homejoy in 2015 spreading rumours of its own entry into the market.

Taking these developments into account, the case of Amazon seems to challenge both Schumpeterian self-descriptions of the digital economy and theories of post capitalism. On one hand it seems like the dynamic and speed of companies' development is at least as much based on the exploitation of human labour as it is on entrepreneurial initiative and innovation. On the other hand, the ever tighter grip of labour control, intensification and value extraction strongly challenges the assumptions of post capitalist theorists that capitalist labour is due to disappear as digitization progresses. Rather, it seems that we can understand current developments in digital capitalism through the perspective of monopoly capital theory: In order to stay in control over markets and hence retain the power of price setting, companies aim to form monopolies by enforcing rise and later closure of their socio-technical ecosystems. As an effect of this process, a situation of competition between large oligopolies arises. In this situation, as classical monopoly capital theory teaches, labour control and labour process rationalization become essential to the goal of profit extraction. Like industrial monopoly capitalism of the 1960s and 70s, digital monopoly capitalism develops new applications of technology in order to raise productivity of labour.

\subsection{Digital Taylorism and Contingency Work}

In order to use our findings drawn mostly from the Amazon case study for a more comparative approach to other digital economy companies, it seems useful to summarize them in more generalizing theoretical terms. We find that Amazon can teach us two lessons in particular about the development of labour in digital capitalism: A new form of digital control, which we call digital Taylorism, and the creation of a new type of labour force as the object of a process of social disembedding (Polanyi 2001) through digital technology. In order to address these phenomena in a way that shows how they represent changes to previous states of labour control and labour force social integration, we will describe them with regard to their historical predecessors. 


\subsubsection{Digital Taylorism}

As we have shown, in Amazon warehouses, a new form of digital Taylorism has emerged that increasingly transfers modes of organizing and rationalizing work from the industrial sector to the service sector. From the perspective of entrepreneurs, Taylorizing industrial work, which began in the early twentieth century, involved two key promises. First, "scientific management" (a term that Frederick Taylor adopted in 1911) of industrial work processes was supposed to lead to enormous increases in productivity. Second, the mechanization of manufacturing came with the promise of a system of comprehensive control over human work. Workers on the assembly line could neither determine autonomously the speed at which they worked, nor did a work process rationalized according to Taylorist principles offer opportunities for workers to structure workflow as they wished, much less to determine the content of work independently. In essence, this was a system for regulating human work through machines. But as more and more steps in production were automated in the twentieth century, the impacts changed the character of industrial work. Increasingly complex knowledge about the functioning of individual machines as well as comprehensive production systems shaped employees' tasks and meant that they could become machine operators rather than mere appendixes of machines. As industrial work gained in status, organizational principles that had previously been the domain of white-collar work entered the industrial sector. Project and group work modes were established, leading to the end of Taylorism, at least in some segments of industry.

In service factories like Amazon, comprehensive control and regulation of humans by machines are returning to the world of work. Today, apps and algorithms have assumed the role of the assembly line. On the one hand, such technologies allow employers to comprehensively monitor their staff, by constantly determining and evaluating their location and work performance. On the other hand, they not only serve as orientation aids for employees; they also directly manage them as they complete tasks. The monitor at a packing station shows what order has to be handled and how; the hand scanner determines the route a worker has to take through the warehouse; the app on the crowdsourcing platform guides workers to the next steps in a particular job.

Classic models of control at the workplace that address service jobs point to bureaucratic schemes in the form of "strategies of social rationalization" that rely on personal control to be implemented (Staab 2014, 341-351). Bureaucratic regulation of the work process is based on dictating the standardization of tasks. However, such rationalization strategies always depend on personalized, direct relationships, within which implementation of the rules is monitored. Empirical evidence shows that hybrid forms that combine technical and social rationalization strategies can currently be observed in many fields of work. In mail and parcel delivery services, for example, GPS devices are increasingly being used to allow management to determine the whereabouts of delivery staff at all times. Whether such data is actually used to control employees depends on whether someone decides to check available information on a particular deliverer. But potential developments in digitization indicate that technical solutions are likely to utilize algorithms to monitor performance automatically. In Amazon's service factories, algorithms for guiding assessment have tended to render personalized evaluations unnecessary since workers' autonomous activities are already so limited that monitoring by management has become superfluous. Wherever digital Taylorism has taken hold, people are again becoming appendixes of machines in certain areas of the world of work. 


\subsubsection{The Contingent Work Force}

As outlined above, expanding forms of digital control apply not only to employees who are responsible for tasks in core areas of the work process that are essential for its smooth functioning. Digitization also offers completely new opportunities for hybrid employment systems within a company. Increasingly, workers are only loosely linked to a company's periphery, from where they can be integrated into the work flow of the core workforce via crowdsourcing models as the need arises, with less and less effort and cost. From the perspective of the sociology of organizations, the differences in working conditions for clickworkers and seasonal employees in Amazon's fulfilment centres are merely gradual. Just like clickworkers, Amazon's seasonal staff represent a systematic transformation of how work is organized that has become possible in digital capitalism.

Under Fordism, a company plant as an organization was not only a site of control; it also offered a certain level of protection from the risks of the marketplace. By virtue of membership in the organization - that is, by being on the staff of a particular company site-employees were generally entailed to the guaranteed benefits of social security systems, collective labour agreements, and labour law standards. Many companies "protect" their employees despite cyclical fluctuation in demand, by abstaining, for example, from lay-offs during such periods either because they are obliged to do so because of collective-bargaining agreements or because it serves their own planning interests. Under post-Fordist conditions, the situation changed. Since the 1990s, at the latest, more and more companies aim to implement considerably more flexible forms of organizing work. Cutbacks in social security systems and less binding collective-bargaining agreements now offer business new opportunities for deregulating jobs, allowing more leeway for adapting personnel policies in response to changes on the market. The growing risks associated with volatile markets have been passed on to employees-a situation that, roughly since the 1990s, has created a vital debate on new forms of precariousness of labour (Castel 2002). Nonetheless, membership in the respective organization still played a role in such models to the extent that management's market rhetoric was chiefly related to employees who belonged to core staff and thus continued to profit from the "remaining"-but still considerable-advantages of standards set by collective agreements and applicable labour law.

In digital capitalism, the company as an organization-that is, as a general medium of social and institutional inclusion-is systematically scaled down. The remaining core staff is complemented with a varying number of "free" workers who no longer enjoy the promise of participation that was linked to belonging to the organization, both in the Fordist and Post-Fordist periods. At first glance, this may appear to be a contradiction, since, as was outlined above, the revolution of markets under digital capitalism targets in particular the systematic incorporation of new market segments, potential competitors, or promising new branches. Closer inspection shows, however, that companies' organizational strategies involve a combination of closed centres and peripheries that are opened to a certain extent (Dolata 2015, 519). In digital capitalism, the formal borders of companies are increasingly tightened, as more and more employees are no longer needed. A satellite system of labour peripheries emerges around the centres. Workers outside the core staff are integrated into the company's production model only temporarily and partially, while they remain permanently excluded from formal membership in the organization. 
The same concept of interaction between compact centres and flexible peripheries is also revealed in organizational strategies for managing labour as a commodity. On the one side there is a stable core of indispensable, highly-qualified employees; on the other, there is a frequently much larger group of peripheral workers for simple tasks in semi-Taylorized work processes. For the latter, neither Fordism's organizational promise of protection, nor the "thumbscrews"-mostly mental-of Post-Fordism can be drawn on as resources (Bergvall-Kåreborn and Howcroft 2014).

As labour becomes redundant, a new type of worker seems to emerge. Karl Marx characterized nineteenth century proletarians as free in two respects: as a free legal subject and as free from any ownership of the means of production; the latter was the reason that he or she was ultimately forced to sell his or her labour as a commodity. In twenty-first century capitalism, free labour is again transformed. In digital capitalism, labour is made available on demand; as a result, a contingent digital workforce (Commission on the Future of Worker-Management Relations 1994) emerges. For these (formally) independent contractors, their status as contingent workers is not protected from competition on the labour market by an employer's contractual guarantees. Companies no longer need to buy employees' compliance by assuming market risks for them, as they do for permanent staff members. Those who offer their labour and are not associated with an institution face contingency in two respects: they depend systematically on the congruence of demand (tasks, assignments) and supply (availability of their labour at the conditions offered) but lack effective influence on the price of their own labour, which depends chiefly on the size and composition of the digital reserve army. The fact that this labour reservoir is growing and increasingly less subject to spatial constraints opens the floodgates for price dumping on the labour market. One could argue that this organizational disintegration only reflects a general process of precarization of work (Castel 2002) that has been going on for a while now. While we agree that contingent digital work is indeed precarious concerning labour contracts and social security, we also see a new aspect to contingent digital labour: Discipline is effectively secured, as described above, not only through fears of growing competition but also with the use of increasingly sophisticated digital control methods. In this respect, digital contingent work differs systematically from what is associated with the precarious labour of post-Fordist capitalism. While the post-Fordist precariat is either self-employed and free of direct control or temporarily integrated into a company and thus in its social system (of course to a lesser extent than core staff members), digital contingent labour is both "free" from social integration into the corporate universe and integrated tightly into a company's' system of control. Increasingly automated direct control has returned, albeit without the benefits that membership in an organization offers employees in classic job forms. All of this is embedded in a context of highly asymmetric constellations of power and access to information. For example, clickworkers often do not even know who has commissioned the tasks they are performing (Strube 2015). The platform that passes on the tasks also serves as an isolating layer that prevents contacts between companies and workers. Industrial capitalism's patrimonial model of care and discipline is thus substituted by a supply-driven gatekeeper model from the politics of organizations. Unauthorized persons have no access.

\section{No End to Capitalism}

The empirical elaborations and tentative theoretical assumptions in this article aimed at challenging theories of post capitalism, which, in the context of this text, have been associated with current works of Jeremy Rifkin and Paul Mason. In their latest books, 
both authors argue for a more or less inevitable end to capitalism. They assume that private accumulation is systematically blocked by the inability of capitalist corporations to create revenues by setting prices as they lose control over the reproduction of their commodities in an economy where people have the power to make most things in non-capitalist production models themselves. Mason states, however, that, in building dominant monopolies, leading digital economy companies could retain the power of price setting while the products they deal with become increasingly cheaper in terms of production costs. Notwithstanding, he argues that these attempts will be failing in the end as such monopolies cannot stop the rise of open source and peer production. In order to challenge these ideas, we asked two questions, applied empirically mostly on the case of Amazon: Is the digital economy really moving towards a state in which corporations lose all control over markets, which then become increasingly decommodified? And second, is there really any end to capitalist labour or at least a reduction in capitalist modes of exploitation connected to the digitization trend?

While we cannot give a definite answer to both questions, close analysis of Amazon and thoughts on the policies of other leading digital corporations bring us to conclusions which challenge the assumptions of post capitalist theories. First, key corporate players of digitization-in particular Amazon, Google, Microsoft, Apple and Facebook-are indeed trying to become powerful monopolies and have partly succeeded in doing so, using network effects of digital platforms, the power of scaling routed in the zero marginal cost logic of digital goods and building socio-technical ecosystems in order to enforce customer retention. Second, it seems that leading digital economy companies tend to develop in part isomorphic structures on the supply side, hence creating a situation of oligopolistic market competition. We drew on basic assumptions of monopoly capital theory, which were elaborated empirically in 1960s to 1980 s industrial sociology, to explain that in this situation of oligopolistic competition, cost cutting, achieved primarily via labour process rationalization, becomes key to the corporation's competitive strategies. In our view, the case study of Amazon and our theoretical assumptions drawn from it offer evidence that strategies of cost cutting especially target the enhancement of digital labour control. Our conclusion is, therefore, that theorists like Mason might be right (although not for the right reasons) in arguing that large digital corporations fail in building stable monopolies. This, however, does not seem to imply any end to capitalist labour. Rather it seems to call for a tightening of the grip of labour control and new modes of exploitation of human labour-phenomena we have addressed with the terms digital Taylorism and digital contingent work. In our view, the current state of digital capitalism resembles a fight for supremacy between large digital corporations, which is based on the enforcement of extraction of value from human labour. Our assumption therefore is that we see nothing like the end of capitalism in the digital economy. Rather, capitalism is maturing in the usage of digital technologies following tracks well known from the history industrial societies.

\section{References}

Bergvall-Kåreborn, Birgitta, and Debra Howcroft. 2014. Amazon Mechanical Turk and the Commodification of Labour. New Technology, Work and Employment 29 (3): 213-223.

Boes, Andreas, Tobias Kämpf, Barbara Langes, and Thomas Lühr. 2015. Landnahme Im Informationsraum: Neukonstituierung Gesellschaftlicher Arbeit in Der 'digitalen Gesellschaft'. WSI-Mitteilungen, no. 2: 77-85. 
Braverman, Harry. 1998. Labor and Monopoly Capital: The Degradation of Work in the Twentieth Century. New York: Monthly Review Press.

Brynjolfsson, Erik, and Andrew McAfee. 2014. The Second Machine Age: Work, Progress, and Prosperity in a Time of Brilliant Technologies. New York: W. W. Norton \& Company.

Burawoy, Michael. 1982. Manufacturing Consent: Changes in the Labor Process Under Monopoly Capitalism. Chicago: The University of Chicago Press.

Castel, Robert. 2002. From Manual Workers to Wage Laborers: Transformation of the Social Question. Piscataway, NJ: Transaction Publishers.

Chandler, Jesse, and Gabriele Paolacci. 2014. Inside the Turk: Mechanical Turk as a Participant Pool. Current Directions in Psychological Science 23 (3): 184-88.

Christensen, Clayton M. 1997. The Innovator's Dilemma. When New Technologies Cause Great Firms to Fail. Boston: Harvard Business School Press.

DiMaggio, Paul, and Walter W. Powell. 2000. Das 'stahlharte Gehäuse' Neu Betrachtet. Institutioneller Isomorphismus Und Kollektive Rationalität in Organisationalen Feldern. In Zeitgenössische Amerikanische Soziologie, edited by Hans-Peter Müller and Steffen Sigmund, 147-173. Opladen: Leske + Budrich.

Dolata, Ulrich. 2015. Volatile Monopole. Konzentration, Konkurrenz Und Innovationsstrategien Der Internetkonzerne. Berliner Journal Für Soziologie 24 (4): 505-29.

Dyer-Witheford, Nick. 2015. Cyber-Proletariat: Global Labour in the Digital Vortex. London: Pluto Press.

Edwards, Richard C. 1979. Contested Terrain: The Transformation of the Workplace in the Twentieth Century. New York: Basic Books.

Frank, Robert H., and Philip J. Cook. 1995. The Winner-Take-All Society: Why the Few at the Top Get So Much More Than the Rest of Us. New York: Penguin Books.

Fuchs, Christian. 2014. Digital Labour and Karl Marx. New York: Routledge.

Fuchs, Christian, and Eran Fisher, eds. 2015. Reconsidering Value and Labour in the Digital Age. Basingstoke: Palgrave Macmillan.

Fuchs, Jochen G. 2013. Amazon Ersetzt Mitarbeiter Durch Roboter. $33 n$, 25 October. www.t3n.de/news/amazon-ersetzt-mitarbeiter-504483.

Hegemann, Lisa. 2014. Wie Amazon Das Weihnachtsgeschäft Überstehen Will. Handelsblatt, October 30. http://www.handelsblatt.com/unternehmen/handelkonsumgueter/amazon-stellt-10-000-saisonkraefte-ein-wie-amazon-dasweihnachtsgeschaeft-ueberstehen-will/10911510.html.

Howe, Jeff. 2006. The Rise of Crowdsourcing. Wired, 6 January. http://archive.wired.com/wired/archive/14.06/crowds.html.

Kwasniewski, Nicolai. 2013. ARD-Dokumentation: Wie Amazon Leiharbeiter Kaserniert. Spiegel Online, February 13. http://www.spiegel.de/wirtschaft/unternehmen/ard-reportagedokumentiert-missstaende-in-der-leiharbeit-bei-amazon-a-883156.html.

Mason, Paul. 2016. Post cappitalism: A Guide to Our Future. London: Penguin Books.

Polanyi, Karl. 2001. The Great Transformation: The Political and Economic Origins of Our Time. Boston: Beacon Press.

Rifkin, Jeremy. 2015. The Zero Marginal Cost Society: The Internet of Things, the Collaborative Commons, and the Eclipse of Capitalism. New York: Macmillan USA.

Rochet, Jean-Charles, and Jean Tirole. 2003. Platform Competition in Two-Sided Markets. Journal of the European Economic Association 1 (4): 990-1029.

Romer, Paul M. 1990. Endogenous Technological Change. Journal of Political Economy 98 (5/2): 71-102.

Rose, Charlie. 2013. Amazon's Jeff Bezos Looks to the Future. 60 Minutes. CBS News. http://www.cbsnews.com/news/amazons-jeff-bezos-looks-to-the-future/.

Schiller, Dan. 1999. Digital Capitalism: Networking the Global Market System. Cambridge, MA: The MIT Press.

Scholz, Trebor. 2012. Digital Labor: The Internet as Playground and Factory. New York: Routledge. 
Schumpeter, Joseph A. 1983. The Theory of Economic Development: An Inquiry into Profits, Capital, Credit, Interest, and the Business Cycle. New Brunswick, NJ: Transaction Books.

Shapiro, Carl, and Hal R. Varian. 1999. Information Rules. A Strategic Guide to the Network Economy. Boston: Harvard Business Press.

Staab, Philipp. 2014. Macht Und Herrschaft in Der Servicewelt. Hamburg: Hamburger Edition.

Stone, Brad. 2013. The Everything Store: Jeff Bezos and the Age of Amazon. Boston: Little, Brown and Company.

Strube, Sebastian. 2015. Vom Outsourcing Zum Crowdsourcing. Wie Amazons Mechanical Turk Funktioniert. In Crowdwork-Zurück in Die Zukunft? Perspektiven Digitaler Arbeit, edited by Christiane Benner, 75-92. Frankfurt/Main: Bund-Verlag.

Sweezy, Paul, and Paul A. Baran. 1966. Monopoly Capital: An Essay on the American Economic and Social Order. New York: Monthly Review Press.

Thiel, Peter, and Blake Masters. 2014. Zero to One: Notes on Startups, or How to Build the Future. New York: Crown Business.

Varian, Hal R. 1997. Grundzüge Der Mikroökonomik. Berlin: De Gruyter.

Wingfield, Nick. 2016. Amazon's Profits Grow More Than 800 Percent, Lifted by Cloud Services. New York Times, 28 July. http://www.nytimes.com/2016/07/29/technology/amazonearnings-profit.html.

Zimmermann, Sophia. 2015. Prime Air: Amazon Reicht Patent Für Lieferdrohne Ein. Heise Online, 9 May. http://www.heise.de/newsticker/meldung/Prime-Air-Amazon-reicht-Patentfuer-Lieferdrohne-ein-2639765.html.

\section{About the Author}

Philipp Staab

Post-Doctoral Researcher, Institute for the History and Future of Work, Berlin, Germany.

PhD Faculty of Social Sciences, University of Kassel, Kassel, Germany. 2013.

Oliver Nachtwey

Visiting Professor in Sociology, Technical University of Darmstadt, Darmstadt, Germany.

PhD Faculty of Social Sciences, Georg-August-University Göttingen, Göttingen, Germany. 2008. 